\title{
DNA vaccination with a gene encoding Toxoplasma gondii Rhoptry Protein 17 induces partial protective immunity against lethal challenge in mice
}

\author{
Hai-Long Wang ${ }^{1, *}$, Yu-Jing Wang ${ }^{2}$, Yan-Jiang Pei ${ }^{3}$, Ji-Zhong $\mathrm{Bai}^{4}$, Li-Tian Yin ${ }^{5}$, Rui Guo ${ }^{2}$, \\ and Guo-Rong Yin ${ }^{1}$ \\ Research Institute of Medical Parasitology, Shanxi Medical University, Taiyuan, Shanxi 030001, PR China \\ 2 Department of Biochemistry and Molecular Biology, Shanxi Medical University, Taiyuan, Shanxi 030001, PR China \\ 3 Department of General Surgery, Xi'an Red Cross Hospital, Xi'an, Shanxi 710000, PR China \\ 4 Department of Physiology, Faculty of Medical and Health Sciences, University of Auckland, Private Bag 92-019, Auckland 1142, \\ New Zealand \\ 5 Department of Physiology, Key Laboratory of Cellular Physiology Co-Constructed by Province and Ministry of Education, \\ Shanxi Medical University, Taiyuan, Shanxi 030001, PR China
}

Received 10 November 2015, Accepted 22 January 2016, Published online 3 February 2016

\begin{abstract}
Toxoplasma gondii is an obligate intracellular apicomplexan parasite that affects humans and various vertebrate livestock and causes serious economic losses. To develop an effective vaccine against $T$. gondii infection, we constructed a DNA vaccine encoding the $T$. gondii rhoptry protein 17 (TgROP17) and evaluated its immune protective efficacy against acute $T$. gondii infection in mice. The DNA vaccine (p3×Flag-CMV-14-ROP17) was intramuscularly injected to $\mathrm{BALB} / \mathrm{c}$ mice and the immune responses of the vaccinated mice were determined. Compared to control mice treated with empty vector or PBS, mice immunized with the ROP17 vaccine showed a relatively high level of specific anti- $T$. gondii antibodies, and a mixed $\operatorname{IgG} 1 / \operatorname{IgG} 2$ a response with predominance of IgG2a production. The immunized mice also displayed a specific lymphocyte proliferative response, a Th1-type cellular immune response with production of IFN- $\gamma$ and interleukin-2, and increased number of $\mathrm{CD} 8^{+} \mathrm{T}$ cells. Immunization with the ROP17 DNA significantly prolonged the survival time $(15.6 \pm 5.4$ days, $P<0.05)$ of mice after challenge infection with the virulent $T$. gondii RH strain (Type I), compared with the control groups which died within 8 days. Therefore, our data suggest that DNA vaccination with TgROP17 triggers significant humoral and cellular responses and induces effective protection in mice against acute $T$. gondii infection, indicating that TgROP17 is a promising vaccine candidate against acute toxoplasmosis.
\end{abstract}

Key words: Toxoplasma gondii, Rhoptry protein 17, DNA vaccine, Protective immunity.

\begin{abstract}
Résumé - La vaccination par ADN avec un gène codant pour la protéine 17 des rhoptries de Toxoplasma gondii induit une immunité protectrice partielle contre une provocation létale chez la souris. Toxoplasma gondii est un Apicomplexa parasite intracellulaire obligatoire, qui affecte l'homme et divers animaux domestiques et provoque de graves pertes économiques. Pour développer un vaccin efficace contre l'infection par $T$. gondii, nous avons construit un vaccin à ADN codant pour la protéine 17 des rhoptries de $T$. gondii (TRAP17) et avons évalué son efficacité protectrice immunitaire contre une infection aiguë par $T$. gondii chez la souris. Le vaccin à ADN (p3 $\times$ Flag-CMV-14-ROP17) a été injecté par voie intramusculaire à des souris $\mathrm{BALB} / \mathrm{c}$ et les réponses immunitaires des souris vaccinées ont été déterminées. Par comparaison avec des souris témoins traitées avec le vecteur vide ou du PBS, les souris immunisées avec le vaccin contre la ROP17 ont montré un niveau relativement élevé d'anticorps spécifiques anti-T. gondii et une réponse $\operatorname{IgG} 1 / \operatorname{IgG} 2$ a mixte avec prédominance de la production d'IgG2a. Les souris immunisées ont également montré une réponse proliférative lymphocytaire spécifique, une réponse immunitaire cellulaire de type Th1 avec production d'IFN- $\gamma$ et d'interleukine-2, et une augmentation du nombre de cellules T $\mathrm{CD}^{+}$. L'immunisation avec l'ADN ROP17 a prolongé de façon significative le temps de survie $(15.6 \pm 5.4$ jours, $P<0.05)$ des souris après infection d'épreuve avec la souche virulente de $T$. gondii RH (type I), par rapport aux groupes de contrôle qui sont morts dans les 8 jours. Par conséquent, nos données
\end{abstract}

\footnotetext{
*Corresponding author: longwty@163.com
}

This is an Open Access article distributed under the terms of the Creative Commons Attribution License (http://creativecommons.org/licenses/by/4.0), which permits unrestricted use, distribution, and reproduction in any medium, provided the original work is properly cited. 
suggèrent que la vaccination par ADN avec TgROP17 déclenche des réponses humorale et cellulaire importantes et induit une protection efficace chez la souris contre une infection aiguë par T. gondii, indiquant que TgROP17 est un candidat vaccin prometteur contre la toxoplasmose aiguë.

\section{Introduction}

Toxoplasma gondii (T. gondii) is an obligate intracellular apicomplexan parasite which can invade a wide range of vertebrate hosts including humans and cause a variety of clinical infections in humans $[19,24]$. T. gondii infection-induced abortions have been reported mostly in sheep but scarcely in cattle, while it evokes stillbirths and neonatal deaths in all types of livestock with serious economic losses [10]. Infected meat can serve as a source of transmission to humans [3]. T. gondii infection thus poses serious public health issues in the world [38]. Currently, there are no drugs available to effectively eliminate the parasite. Therefore, development of an effective vaccine against $T$. gondii infection represents a promising alternative for human health and animal husbandry [44].

Among the putative vaccine candidates for toxoplasmosis, the rhoptry proteins (ROPs) appear to be particularly promising $[4,46]$. ROPs are secreted by rhoptries, which are apical secretory organelles of $T$. gondii, and these proteins are involved in parasitic invasion $[2,27]$. Some ROPs (i.e. ROP5, ROP16, and ROP18) act as serine-threonine kinases, known as ROP kinases (ROPK), and play the role of virulence factors [11, 15, 40]. ROP17 belongs to the ROP2 superfamily of predicted ROPKs [9]. It possesses a key ATP-binding domain and conserved residues in its catalytic triad (KDD) region [23], and has been proven to be a ROPK $[11,34]$.

Recently, a number of ROPs including ROP5, ROP9, ROP13, ROP16, and ROP18 have been used as immunogens for vaccine development to evoke considerable cellular and humoral immune responses that partly protected mice against acute infection by $T$. gondii $[4,18,36,43,46]$. Our previous study also showed that recombinant rhoptry proteins 17 (rTgROP17) as a candidate protein vaccine could partially protect mice against infection by $T$. gondii via intranasal immunization [35]. However, the protective role of ROP17 as a DNA vaccine has not been tested. In the present study, we constructed the ROP17-expressing eukaryotic expression vector p3 $\times$ Flag-CMV-14-ROP17 as a DNA vaccine to immunize $\mathrm{BALB} / \mathrm{c}$ mice, and investigated immune responses and protective efficacy against acute $T$. gondii infection.

\section{Materials and methods}

\section{Mice, parasites, and recombinant eukaryotic expression plasmid}

Female BALB/c mice aged 6 weeks were purchased from the Institute of Laboratory Animal Science of the Chinese Academy of Medical Science (Beijing, China). All mice were maintained under standard, pathogen-free conditions and provided with rodent feed and water ad libitum. All surgeries were performed under sodium pentobarbital anesthesia and all animal experiments were conducted according to institutional guidelines for animal ethics. The tachyzoites of the virulent T. gondii RH strain were maintained and collected from the peritoneal cavity of infected BALB/c mice in our laboratory according to a previously described method $[20,41]$ and used as a challenge for the immunized mice.

The eukaryotic expression vector p3×Flag-CMV-14ROP17 was constructed and full length ROP17 was expressed (molecular weight, approximately $70 \mathrm{KDa}$ ) in HEK 293T cells as in our previous study [34]. Briefly, total tachyzoite RNA was extracted from $5 \times 10^{8}$ tachyzoites using Trizol reagent and the first strand of cDNA was synthesized using the HiFiMMLV cDNA Kit (CWBIO, China). The coding region of rop17 of T. gondii (1821 bp, which encodes a 607-amino acid protein. GenBank Accession No. AM075203.1) was amplified via polymerase chain reaction (PCR) from the first strand of cDNA. The forward primer was 5'-CGGGGTACCGCCATGGAGTTGGTGTTGTGCTTTGT-3', the reverse primer was 5'-CGCGGATCCCTCCTTCTGTAATAAAGCCGCCT-3', containing the Kpn I and Bam H I restriction sites (underlined), respectively. PCR amplification was performed with initial denaturation at $94{ }^{\circ} \mathrm{C}$ for $5 \mathrm{~min}$ followed by 30 consecutive cycles of denaturation at $94{ }^{\circ} \mathrm{C}$ for $30 \mathrm{~s}$, annealing at $58{ }^{\circ} \mathrm{C}$ for $30 \mathrm{~s}$, and extension at $72{ }^{\circ} \mathrm{C}$ for $90 \mathrm{~s}$, and then a final extension at $72{ }^{\circ} \mathrm{C}$ for $10 \mathrm{~min}$. The amplified products were analyzed by electrophoresis on a $1 \%(\mathrm{w} / \mathrm{v})$ agarose gel. The $\mathrm{p} 3 \times$ FlagCMV-14 vector and ROP17 PCR products were digested with Kpn I and Bam $\mathrm{H}$ I and then purified from agarose gel using the CWBIO Gel Extraction Kit. The digested p3 $\times$ Flag-CMV14 vector and ROP17 PCR products were linked by $\mathrm{T}_{4}$ ligase and then transformed into DH $5 \alpha$ host bacteria cells. Positive transformants ( $\mathrm{p} 3 \times$ Flag-CMV-14-ROP17) were selected and confirmed by DNA sequencing. Recombinant plasmid DNAs were then extracted using GoldHi EndoFree Plasmid Maxi Kit (CWBIO, China) and their concentrations were determined spectrophotometrically. Following dilution with sterile phosphate-buffered saline (PBS) to a final concentration of $1 \mu \mathrm{g}$ / $\mu \mathrm{L}$, the recombinant plasmid DNAs were stored at $-20^{\circ} \mathrm{C}$ until used. The expression of ROP17 was verified by transfecting the p3 $\times$ Flag-CMV-14-ROP17 plasmid DNA into HEK $293 \mathrm{~T}$ cells and then detected via Western blot using Flag monoantibody [34].

\section{Ethics statement and animal experiments}

All experimental animal procedures were approved by the Ethics Committee of Animal Experiments of Shanxi Medical University (Permit Number: 20110320-1). Surgeries were performed under sodium pentobarbital anesthesia, and all possible efforts were made to minimize the suffering of the 
experimental mice according to the protocols from the Laboratory Animal Use and Care Committee of Shanxi Medical University (SXMU-2011-16).

Mice (16/group) were injected intramuscularly (buttocks) with $100 \mu \mathrm{g}$ of $\mathrm{p} 3 \times$ Flag-CMV-14-ROP17 plasmid DNA (in $100 \mu \mathrm{L}$ sterile PBS; needle length, $16 \mathrm{~mm}$ ) in the thigh skeletal muscle and boosted twice with the same dose at 2-week intervals. Control mice received PBS alone or empty p $3 \times$ Flag-CMV-14 vector. Blood was collected from the tail veins of six mice in each group at weeks $0,2,4$, and 6 and stored at $-20{ }^{\circ} \mathrm{C}$ until assayed for antibody titers.

Two weeks after the last immunization, six mice per group were sacrificed and splenocytes were harvested under aseptic conditions for cytokine assays and lymphocyte proliferation assays. The remaining mice (10/group) in all groups were intraperitoneally (i.p.) challenged with $1 \times 10^{3} T$. gondii $\mathrm{RH}$ strain tachyzoites suspended in $100 \mu \mathrm{L}$ PBS and their survival periods were recorded daily until all mice died.

\section{Antibody titers and isotype determination}

ROP17-specific antibodies were analyzed by enzymelinked immunosorbent assay (ELISA) as previously described [35]. In brief, microtiter plates were coated with recombinant TgROP17 protein (rTgROP17, $750 \mathrm{ng} / \mathrm{well})$ in $100 \mu \mathrm{L}$ carbonate buffer $(50 \mathrm{mM}, \mathrm{pH} 9.6)$ overnight at $4{ }^{\circ} \mathrm{C}$; nonspecific binding sites were blocked with $5 \%$ bovine serum albumin (BSA) in PBS for $1 \mathrm{~h}$ at $37^{\circ} \mathrm{C}$. Serum samples diluted in PBS (1:200) were added to the wells (100 $\mu \mathrm{L} /$ well) and incubated at $4{ }^{\circ} \mathrm{C}$ overnight. HRPconjugated goat anti-mouse $\operatorname{IgG}$ was used as the secondary antibody, and HRP-conjugated goat anti-mouse IgG1 or IgG2a (Proteintech Group Inc., Chicago) was used for isotype analyses. Immune complexes were revealed by incubation with orthophenylene diamine and $0.15 \% \mathrm{H}_{2} \mathrm{O}_{2}$, dark incubated for $30 \mathrm{~min}$ and the enzyme reaction was terminated by the addition of $1 \mathrm{M} \mathrm{H}_{2} \mathrm{SO}_{4}$. The optical density was read at $492 \mathrm{~nm}$ (OD492) with an ELISA reader (Epoch Multi-Volume Spectrophotometer System, BioTek, USA). All samples were run in triplicate.

\section{Lymphocyte proliferation assay}

Spleen cells were collected using published methods [20] and resuspended in RPMI-1640 medium supplemented with $10 \%$ fetal calf serum. Cells were seeded in flat-bottom 96-well microtiter plates at a density of $5 \times 10^{5}$ cells per well and were cultured in the presence of rTgROP17 $(10 \mu \mathrm{g} / \mathrm{mL})$, Concanavalin A (Con A; $5 \mu \mathrm{g} / \mathrm{mL}$; positive control), or RPMI-1640 medium alone (negative control) at $37{ }^{\circ} \mathrm{C}$ in a $5 \% \mathrm{CO}_{2}$ incubator. The proliferative activity was measured using Cell Counting Kit-8 reagent (Dojindo Laboratories; Kumamoto, Japan) according to the manufacturer's instructions. The stimulation index $\left(\mathrm{SI}=\right.$ the mean $\mathrm{OD}_{450}$ values from recombinant antigen-stimulated cultures/the mean $\mathrm{OD}_{450}$ values from nonstimulated cultures) of each group was calculated. All assays were performed in triplicate.

\section{Cytokine assays}

Cytokines were measured according to the method described previously [33]. The splenocytes $\left(1.5 \times 10^{6}\right)$ were cultured in triplicate in flat-bottom 24-well microtiter plates and stimulated with $10 \mu \mathrm{g}$ of rTgROP17. Cell-free supernatants were collected and assayed for interleukin-2 (IL-2) and interleukin-4 (IL-4) at $24 \mathrm{~h}$, for interleukin-10 (IL-10) at $72 \mathrm{~h}$, and for gamma-interferon (IFN- $\gamma$ ) at $96 \mathrm{~h}$. The concentrations of IL-2, IL-4, IL-10, and IFN- $\gamma$ were determined with a commercial ELISA Kit (NeoBioscience, China) according to the manufacturer's instructions. All assays were performed in triplicate. The detection limits of the assays were $15.6 \mathrm{pg} / \mathrm{mL}$ for IL-2, IL-4, IFN- $\gamma$, and $31.25 \mathrm{pg} / \mathrm{mL}$ for IL-10.

\section{Flow cytometry}

For phenotypic analysis of splenocytes, a single cell suspension was prepared as described above, and $1 \times 10^{6}$ cells in $50 \mu \mathrm{L}$ were delivered to each tube already containing $10 \mu \mathrm{L}$ of Allophycocyanin (APC)-labeled anti-mouse CD4, $20 \mu \mathrm{L}$ of phycoerythrin (PE)-labeled anti-mouse CD8, or $20 \mu \mathrm{L}$ of fluorescein isothiocyanate (FITC)-labeled anti-mouse CD3 antibodies (all from eBioscience) and incubated at $4{ }^{\circ} \mathrm{C}$ for $20 \mathrm{~min}$ in the dark. After washing, the cells were fixed with FACScan buffer (PBS containing 1\% BSA and $0.1 \%$ sodium azide) and 2\% paraformaldehyde. The fluorescence profile of each sample (at least 10,000 cells) was analyzed on FACSCalibur flow cytometer (BD Biosciences) using SYSTEM II software (Coulter).

\section{Statistical analysis}

Statistical analysis was performed using SPSS software. Normal distribution tests of data within each group were initially determined by the Shapiro-Wilk analysis, and $P>0.10$ was defined as normally distributed. All results are presented as means $\pm \mathrm{SD}$, including antibody levels, lymphoproliferation assays, cytokine productions, and percentages of $\mathrm{CD}^{+}$and $\mathrm{CD}^{+} \mathrm{T}$ cells. Comparisons were made between the different groups by one-way ANOVA and $P<0.05$ was defined as statistically different. GraphPad Prism 5.0 software was used to construct the survival curve and the differences of survival time were calculated using rank-sum test, as the survival data among different groups were abnormally distributed.

\section{Results}

\section{Humoral response induced by DNA vaccination}

To determine the humoral immune responses of the DNA vaccine p3 $\times$ Flag-CMV-14-ROP17, levels of anti-ROP17 antibodies in all the test animal sera were measured by ELISA. As shown in Figure 1, a significant increase of ROP17-specific IgGs was evident in the mice immunized with $\mathrm{p} 3 \times$ Flag-CMV14-ROP17 for 4 weeks $(P<0.05)$ and reached much higher levels at 6 weeks with successive immunization $(P<0.01)$. 


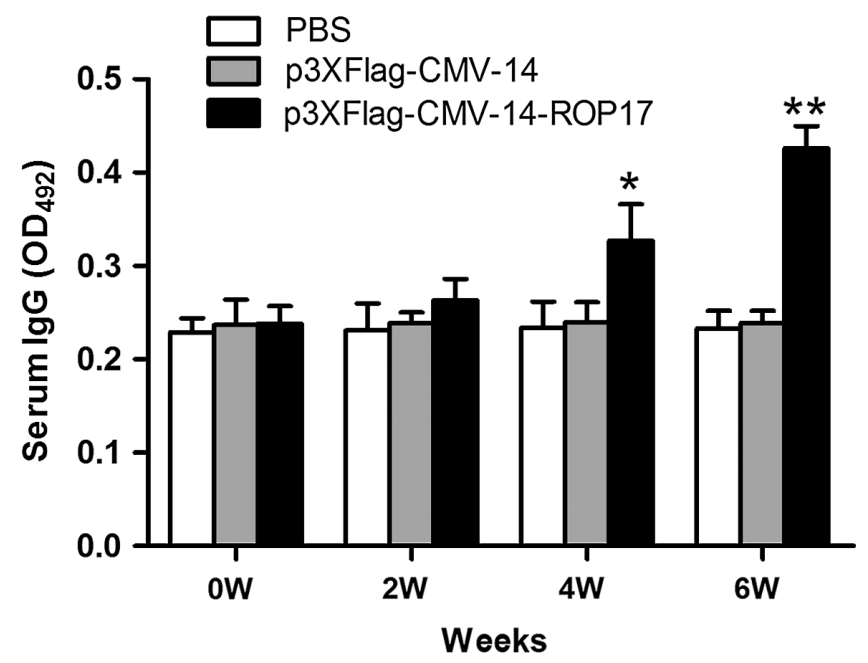

Figure 1. Dynamics of antibody production in ROP17 DNAimmunized $\mathrm{BALB} / \mathrm{c}$ mice and controls. Levels of specific antiROP17 IgG titers in the sera of various $\mathrm{BALB} / \mathrm{c}$ mice were determined by ELISA under the same conditions. Results are expressed as means $\pm \mathrm{SD}(n=6) .{ }^{*} P<0.05,{ }^{* *} P<0.01$ relative to control groups.

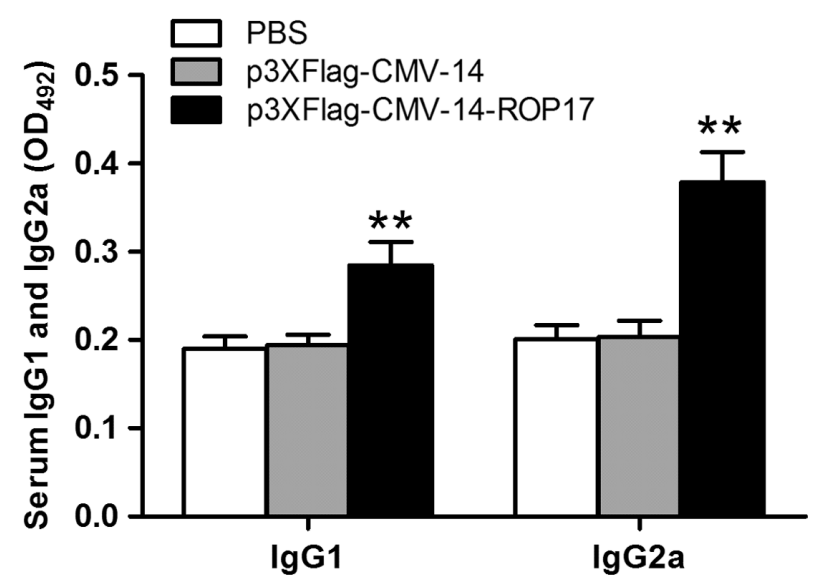

Figure 2. Determination of $T$. gondii-specific IgG subclass titers in ROP17 DNA-immunized BALB/c mice and controls. The IgG subtypes were determined by ELISA as stated in Figure 1. Results are expressed as means $\pm \mathrm{SD}(n=6) . * P<0.05, * * P<0.01$ relative to control groups.

In contrast, mice immunized with control p3×Flag-CMV-14 DNAs or treated with PBS had no detectable change of antiROP17 antibodies. The antibodies generated in the ROP17 DNA-immunized mice were about twofold those determined in the control mice.

We next characterized whether a Th1 or Th2 response was elicited in the immunized mice by evaluating the distribution of IgG subtypes (IgG1 and IgG2a) against ROP17 at two weeks after the last immunization. As shown in Figure 2, ROP17 vaccination induced significant productions of antigen-specific IgG1 and IgG2a antibodies $(P<0.05)$ and a higher level of isotype IgG2a antibodies was observed. These results indicated that ROP17 DNA vaccination could elicit both Th1- and Th2-specific but more Th1-type shifted humoral responses $(\mathrm{IgG} 2 \mathrm{a} / \mathrm{IgG} 1$ ratio $>1)$ [22].

\section{Cytokine production by spleen cells from mice immunized with ROP17 DNA vaccines}

To test the possible role of cell-mediated immunity in the mice immunized with the ROP17 vaccines, we analyzed the levels of cytokine (IFN- $\gamma$, IL-2, IL-4, and IL-10) productions in the tissue culture media of spleen cells isolated from the immunized animals and stimulated with rTgROP17 proteins. As shown in Table 1, compared to PBS or empty vector controls, spleen cells from $\mathrm{p} 3 \times$ Flag-CMV-14-ROP17 immunized mice were able to produce large amounts of IFN- $\gamma$ and IL-2 $(P<0.05)$ with only slightly increased production of IL-4 and IL-10 $(P>0.05)$. These data suggest that ROP17 DNA vaccination evokes predominately Th1-type cellular immune responses $[22,30]$.

\section{Cellular proliferative response induced by DNA vaccination}

To determine the proliferative immune responses of mice to ROP17 DNA vaccination, splenocytes were harvested 2 weeks after the third immunization from the mice. As shown in Table 1, the splenocyte stimulation indices (SIs) of the mice that were immunized with $\mathrm{p} 3 \times$ Flag-CMV-14-ROP17 were significantly greater than those of the control groups $(P<0.01)$. The splenocytes from all experimental groups proliferated to comparable levels in response to ConA, a well-defined stimulator of lymphocyte proliferation [7]. These results further confirm that ROP17 DNA immunization could trigger cellmediated immunity in mice.

\section{Phenotypic T lymphocyte induction by DNA vaccination}

To explore whether any specific type of $\mathrm{T}$ lymphocyte was involved in the immune response to ROP17 vaccination, FACScanning experiments were performed with fluorescently labeled splenocytes using CD3, CD4, and CD8 antibodies. The total mouse spleen cells were quantified and the percentages of $\mathrm{CD}^{+} / \mathrm{CD}^{+}$and $\mathrm{CD} 3^{+} / \mathrm{CD} 8^{+} \mathrm{T}$ cells in each group were determined. To avoid false positives, we used mouse FITC-IgG, PE-IgG, and APC-IgG to analyze the spleen cells isolated from ROP17-vaccinated mice as a quality control (Fig. 3A). As shown in Figures 3B and 3C, a slightly higher level of $\mathrm{CD}^{+} / \mathrm{CD}^{+} \mathrm{T}$ lymphocytes was visualized in the ROP17-immunized mice. In contrast, a greater percentage of $\mathrm{CD}^{+} / \mathrm{CD}^{+} \mathrm{T}$ cells was observed in the ROP17-vaccinated mice than those in the control groups $(P<0.05)$. No difference in the level of these $\mathrm{CD}^{+} / \mathrm{CD}^{+}$ and $\mathrm{CD}^{+} / \mathrm{CD}^{+} \mathrm{T}$-cell subtypes was seen between the two control groups $(P>0.05)$. These data suggest that ROP17 DNA vaccination-induced immunity is also $\mathrm{CD}^{+} \mathrm{T}$ cellmediated in mice. 
Table 1. Cellular proliferation and cytokine production by splenocytes isolated from ROP17 DNA-immunized BALB/c mice and controls.

\begin{tabular}{lccrrr}
\hline Groups* & \multicolumn{2}{c}{ Cytokine production $(\mathrm{pg} / \mathrm{mL})^{* *}$} & \multicolumn{2}{c}{ Lymphocyte SI } \\
\cline { 2 - 5 } & \multicolumn{1}{c}{ IFN- $\gamma$} & \multicolumn{1}{c}{ IL-2 } & IL-4 & \multicolumn{1}{c}{ IL-10 } \\
\hline PBS & $41.29 \pm 6.73^{\mathrm{a}}$ & $79.26 \pm 5.35^{\mathrm{a}}$ & $78.84 \pm 4.37^{\mathrm{a}}$ & $63.31 \pm 5.13^{\mathrm{a}}$ & $1.02 \pm 0.11^{\mathrm{a}}$ \\
p3×Flag-CMV-14 & $45.17 \pm 6.93^{\mathrm{a}}$ & $81.14 \pm 5.71^{\mathrm{a}}$ & $76.63 \pm 5.15^{\mathrm{a}}$ & $66.457 \pm 5.26^{\mathrm{a}}$ & $1.163 \pm 0.12^{\mathrm{a}}$ \\
p3×Flag-CMV-14-ROP17 & $186.17 \pm 11.47^{\mathrm{b}}$ & $158.41 \pm 11.38^{\mathrm{b}}$ & $75.63 \pm 2.73^{\mathrm{a}}$ & $70.25 \pm 4.74^{\mathrm{a}}$ & $2.14 \pm 0.23^{\mathrm{b}}$ \\
\hline
\end{tabular}

${ }^{*} n=6$ per group.

* Splenocytes were harvested from the mice 2 weeks after the final immunization. Results are presented as means \pm the standard errors of three replicate experiments. Values for IFN- $\gamma$ are for $96 \mathrm{~h}$, values for IL-10 are for $72 \mathrm{~h}$, and values for IL-2, IL-4 are for $24 \mathrm{~h}$. Letter a indicates no statistical difference was observed $(P>0.05)$, and letter $\mathrm{b}$ means significant difference within each cytokine or lymphocyte SI group (compared with PBS or empty vector group, $P<0.05$ ).

\section{Protective efficacy of DNA vaccination against T. gondii acute infection in mice}

To assess the protective immunity of $\mathrm{p} 3 \times$ Flag-CMV-14ROP17, mice were challenged with $1 \times 10^{3}$ tachyzoites of the RH strain at 2 weeks after the final immunization. As the $\mathrm{RH}$ virulent strain is non-cystogenic [8, 32], we determined survival rather than tissue cyst burden in the infected mice to assess the protective efficiency of the DNA vaccine. As shown in Figure 4, the survival periods of the mice that were immunized with the ROP17 vaccine ranged from 7 to 21 days, while the control mice died between days 4 and 8 after the challenge $(P<0.01)$. These results indicated that immunization with ROP17 DNAs could prolong survival in BALB/c mice.

\section{Discussion}

Various $T$. gondii rhoptry proteins, such as ROP5, ROP8, ROP9, ROP13, ROP16, ROP18, and ROP38, have been evaluated as potential vaccine candidates for toxoplasmosis. Here we show that ROP17 is also a potential vaccine candidate. ROP17 DNA vaccination prolongs the survival of mice for $15.6 \pm 5.4$ days following a challenge infection with tachyzoites of the RH strain (Fig. 4). Previous DNA vaccination trials also gave a similar mice survival time of $24.9 \pm 2.3$ for ROP13 and $21.6 \pm 9.9$ days for ROP16 [36, 42]. Similar immunization studies indicated that longer mice survival was achievable with ROP8 (29 days) and ROP18 DNAs (27.9 \pm 15.1 days) [21, 43], whereas shorter protection of mice was obtained with ROP9 $(12.9 \pm 2.9$ days $)$ and ROP38 DNAs $(8.1 \pm 0.75$ days $)$ $[4,39]$. These data together suggest that ROP17 DNA vaccination can confer a high degree of immune protection in mice.

Generally, specific-IgG antibodies against $T$. gondii can prevent the parasite from attaching to its host cell receptors and promote macrophages to kill intracellular parasites, which is important in controlling $T$. gondii infection and preventing reactivation [26]. In the present study, an elevated level of anti-ROP17 antibodies was detected in mice immunized with ROP17 DNAs in comparison with those of their control groups (Fig. 1). A mixed IgG1/IgG2a response but a predominant production of IgG2a was also observed in mice immunized with ROP17 vaccine but not in the empty vector or PBS controls
(Fig. 2). Together, these data indicate the involvement of a Th1-type shift of both Th1- and Th2-specific humoral responses during ROP17 DNA vaccination.

It is well known that $\mathrm{T}$ cell-mediated adaptive immune responses are important to determine the course of $T$. gondii infection [16]. In the present study, a significant proliferative response of splenocytes was detected following ROP17 DNA immunization, indicating the activation of cellular immune responses. Additionally, ROP17 DNA vaccination also significantly boosted the percentage of $\mathrm{CD}^{+} \mathrm{T}$ cells, whereas the number of $\mathrm{CD}^{+} \mathrm{T}$ cells was similar to that of the control groups (Fig. 3). Although this $\mathrm{CD}^{+}$response may be lower than that from natural infection [25], this is consistent with the notion that $\mathrm{CD}^{+} \mathrm{T}$ cells constitute the major cellular $\mathrm{T}$ cell subset which is involved in acquired immune protection against $T$. gondii [12]. Therefore, our data suggest that ROP17 DNA vaccination-induced cellular immune responses involve a specific population of $\mathrm{CD}^{+} \mathrm{T}$ cells.

In agreement with the above observations, elevated levels of both IFN- $\gamma$ and IL-2 cytokines were detected in isolated spleen cells from the ROP17-immunized mice (Table 1), suggesting a Th1-type immune response. The finding of slightly increased production of IL-4 and IL-10 from spleen cells of the ROP17-immunized mice (Table 1) further indicates a possible role of Th2-type response as well [23, 24]. A Th1-dominated immune response is consistent with the observation of increased IgG antibody subtypes and high ratio of IgG2a to IgG1 antibodies in the mice immunized with ROP17 DNA vaccines (Figs. 1 and 2). This is supported by the findings that Th1-type immune response plays a critical role in protective immunity against $T$. gondii [28], and that Th2-type immune response is required during the early phase of acute $T$. gondii infection [1]. Taken together, all these data support a role for Th1-type dominated and both humoral and cell-mediated immune responses in the mice immunized with the ROP17 DNA vaccines.

To determine the protective effect of ROP17 DNA vaccine against toxoplasmosis, we used the virulent $T$. gondii $\mathrm{RH}$ strain because it causes severe damage in animals and has been widely used to assess the protective efficacy of novel antigens against toxoplasmosis $[5,13,37]$. As ROP $17 \mathrm{~s}$ across the three genotypes of $T$. gondii share over $99 \%$ of amino acid sequence identity as determined in our previous study [34], although there 
(A)

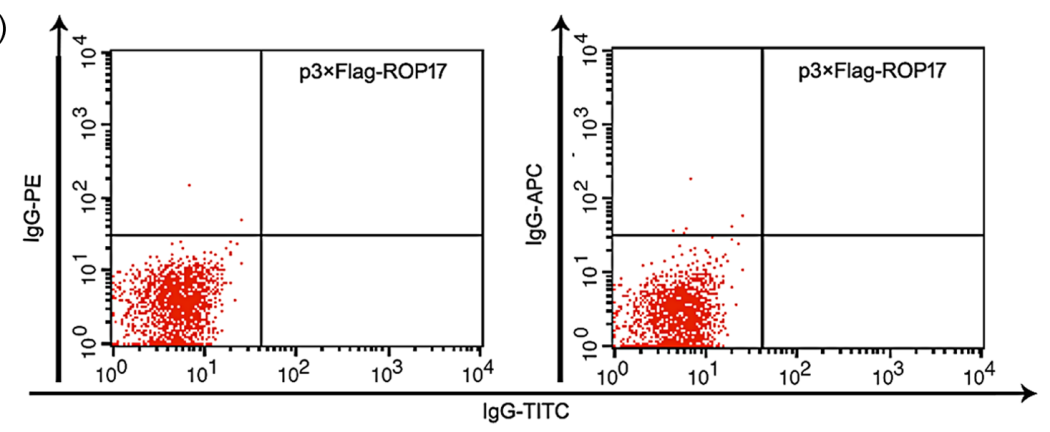

(B)

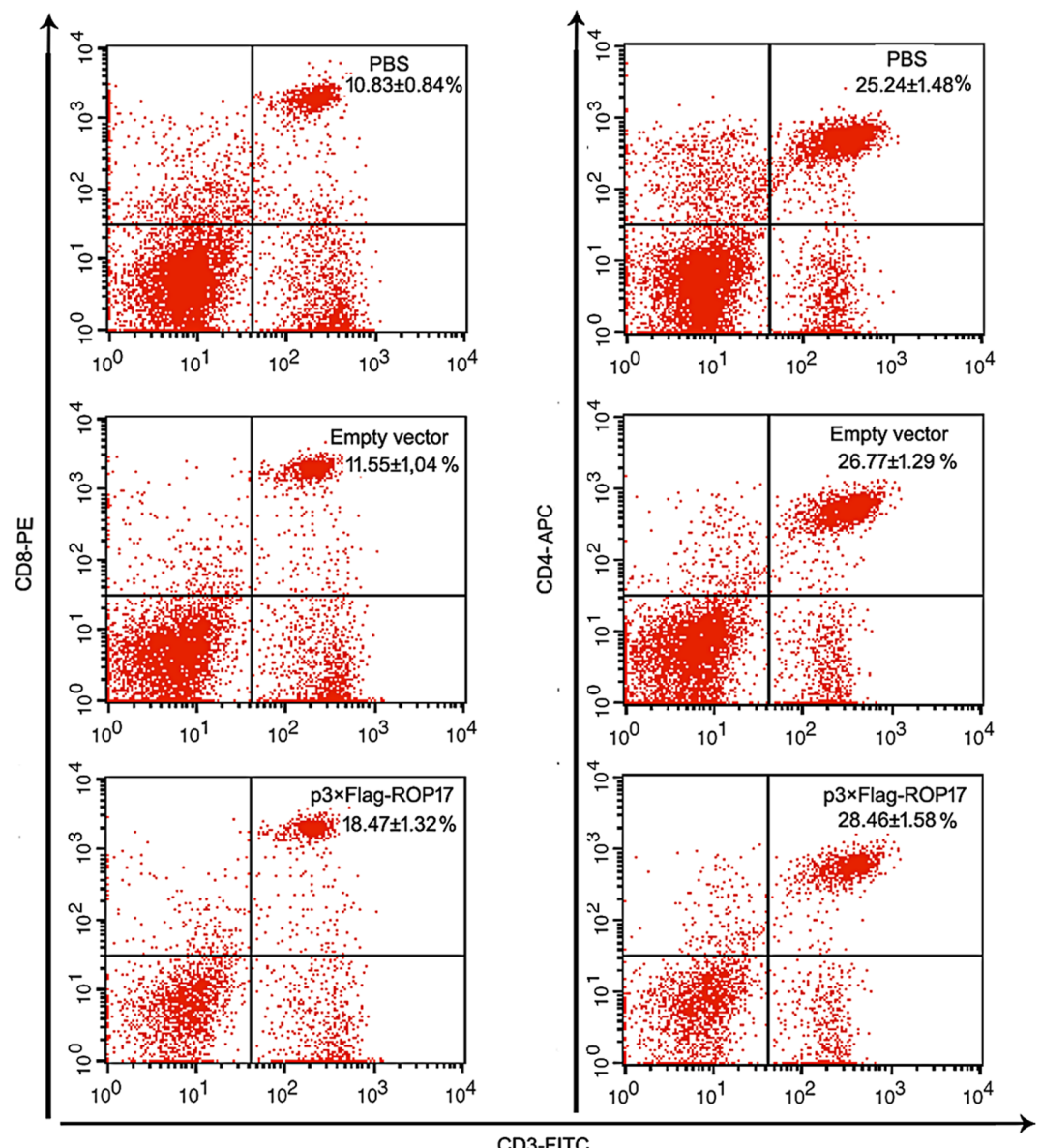

(C)
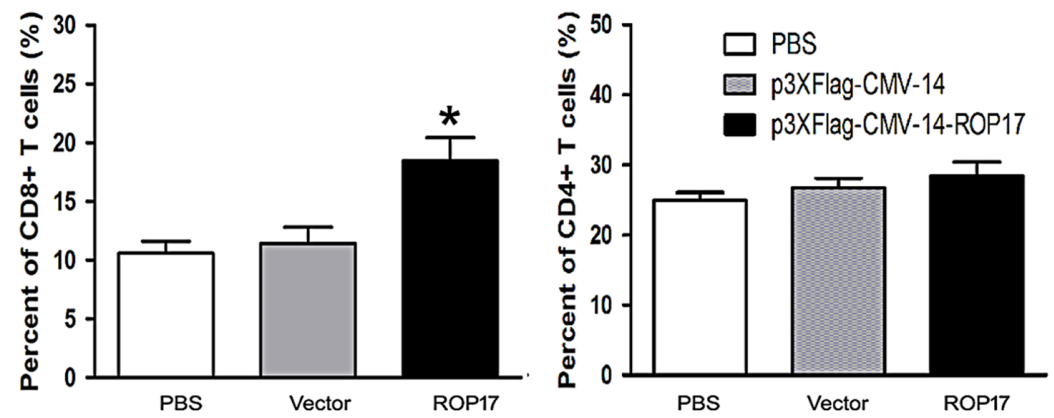

Figure 3. Lymphocyte subpopulations determined in ROP17 DNA-immunized mice by FACS. (A) The total mouse spleen cells were analyzed by using mouse FITC-IgG, PE-IgG, and APC-IgG for quality control. (B and C) The percentages of $\mathrm{CD} 3^{+} / \mathrm{CD}^{+}{ }^{+}$and $\mathrm{CD}^{+} / \mathrm{CD}^{+} \mathrm{T}$ lymphocytes in the total spleen cells were calculated using flow cytometry analysis. Results are expressed as mean values $\pm \operatorname{SD}(n=6)$. $* P<0.05$ relative to control groups. 


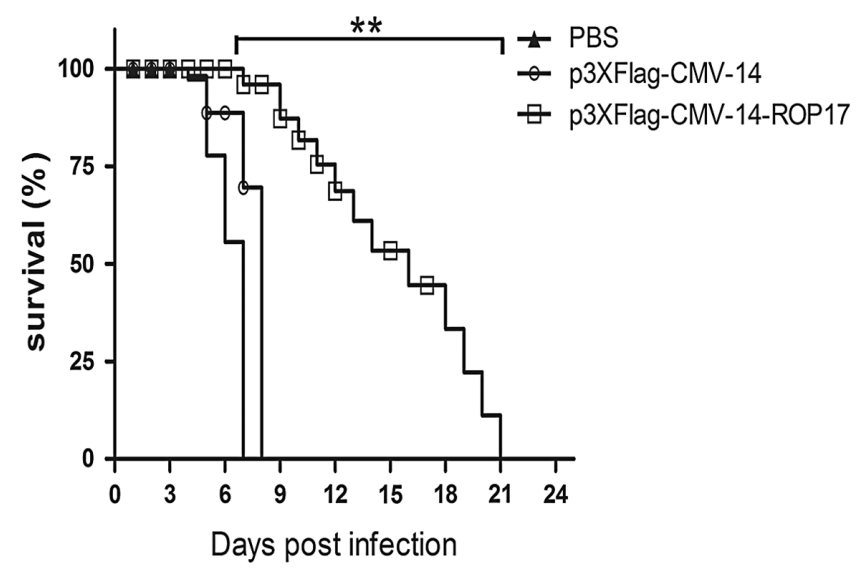

Figure 4. Protection of $\mathrm{BALB} / \mathrm{c}$ mice against $T$. gondii acute infection. Survival curves of ROP17 DNA-immunized and control $\mathrm{BALB} / \mathrm{c}$ mice were determined following lethal challenges with 1000 tachyzoites of virulent $T$. gondii RH strain at 2 weeks after the last immunization. Results are representative of two independent experiments and values are presented as means \pm SD $(n=10)$. $* * P<0.01$ relative to the control groups.

were $\mathrm{A}+\mathrm{T}$ contents that varied from $49.45 \%$ to $50.11 \%$ and nucleotide polymorphisms at 33 positions among strains from different hosts and geographical locations [45], a protection test against type II or III $T$. gondii by the ROP17 DNA vaccine was not included in this study. In our previous studies, recombinant T. gondii ROP17 protein (rTgROP17) has been used as a vaccine candidate to elicit protective immunity against acute T. gondii infection in mice. This protein vaccine induced both systemic and local immune responses and provided a $50 \%$ increase in survival rate and longer survival time [35]. Compared to the ROP17 protein vaccine, ROP17 DNA vaccine in the present study provided limit protection against acute $T$. gondii infection. One possible reason for this difference may be the low levels of antibody generated in the ROP17 DNAimmunized mice, being only twice as high as those in control mice, and lower than those elicited by rTgROP17 vaccines. Since IgG-dependent phagocytosis, cytotoxicity, or complement-mediated lysis are crucial mechanisms for resistance to tachyzoites [26], the relatively low levels of antibodies produced during the ROP17 DNA immunization might not be sufficient to prevent acute infections. Likewise, low levels of IL-4 and IL-10 cytokines raised in the ROP17 DNA-immunized mice (relative to the control animals) may not promote sufficient mast cell responses which play an important role in modulating acute inflammatory pathogenesis and parasite clearance during $T$. gondii infection [14]. This is consistent with the relatively low levels of specific-IgG antibodies found in these mice. In addition, relatively low level of $\mathrm{CD}^{+}$response compared with those in natural infection with a non-lethal strain [29], and a low level of $\mathrm{CD}^{+} \mathrm{T}$ response in these ROP17 DNAimmunized mice might be another reason for the low level of protection against acute $T$. gondii infection in the present study because only the synergy between $\mathrm{CD}^{+}$and $\mathrm{CD} 4^{+} \mathrm{T}$ cells can provide efficient protection against $T$. gondii [6]. Finally, the route of vaccine administration by intramuscular ROP17 DNA injection may also explain its limited protective effects, whereas intranasal rTgROP17 immunization induces strong secretory $\operatorname{IgA}$ (SIgA) immune responses in mucosal sites where SIgA serves as the first line of defense in protecting the intestinal epithelium from enteric toxins and pathogenic microorganisms like Toxoplasma [31].

In conclusion, our results demonstrate that immunization with ROP17 DNA vaccines evokes both humoral and cellular but Th1-dominated immune responses and prolongs the survival time of these mice upon acute $T$. gondii infection. Despite the partial protective efficacy of the DNA vaccine, ROP17 appears to be a potential candidate for the development of vaccines against toxoplasmosis. The immune efficacy of this ROP17-based DNA vaccine may well be improved through its combination with other effective antigens such as ROP18 or adaptive adjuvants such as IL-12 and IL-15 [17].

Acknowledgements. This work was supported by the National Natural Science Foundation of China (No. 81541138), the Fund Program for the Scientific Activities of Selected Returned Overseas Professionals in Shanxi Province (No. 2014779), the Natural Science Fund of Shanxi Province (No. 2012011036-2), the Research Fund for Doctoral Program of Shanxi Medical University (No. 03201307), and the Biology Postdoctoral Mobile Research Station of Shanxi Medical University.

\section{References}

1. Bessieres MH, Swierczynski B, Cassaing S, Miedouge M, Olle P, Seguela JP, Pipy B. 1997. Role of IFN-gamma, TNFalpha, IL4 and IL10 in the regulation of experimental Toxoplasma gondii infection. Journal of Eukaryotic Microbiology, 44(6), $87 \mathrm{~S}$.

2. Bradley PJ, Sibley LD. 2007. Rhoptries: an arsenal of secreted virulence factors. Current Opinion in Microbiology, 10(6), 582-587.

3. Buxton D, Maley SW, Wright SE, Rodger S, Bartley P, Innes EA. 2007. Toxoplasma gondii and ovine toxoplasmosis: new aspects of an old story. Veterinary Parasitology, 149(1-2), 25-28.

4. Chen J, Zhou DH, Li ZY, Petersen E, Huang SY, Song HQ, Zhu XQ. 2014. Toxoplasma gondii: protective immunity induced by rhoptry protein 9 (TgROP9) against acute toxoplasmosis. Experimental Parasitology, 139, 42-48.

5. Daryani A, Sharif M, Dadimoghaddam Y, Souteh MB, Ahmadpour E, Khalilian A, Sarvi S, Farazmand T, Kalani H, Rasouli M. 2014. Determination of parasitic load in different tissues of murine toxoplasmosis after immunization by excretory-secretory antigens using real time QPCR. Experimental Parasitology, 143, 55-59.

6. Dupont CD, Christian DA, Selleck EM, Pepper M, LeneyGreene M, Harms Pritchard G, Koshy AA, Wagage S, Reuter MA, Sibley LD, Betts MR, Hunter CA. 2014. Parasite fate and involvement of infected cells in the induction of $\mathrm{CD}^{+}$and $\mathrm{CD}^{+} \mathrm{T}$ cell responses to Toxoplasma gondii. PLoS Pathogens, 10(4), e1004047.

7. Dziadek B, Gatkowska J, Grzybowski M, Dziadek J, Dzitko K, Dlugonska H. 2012. Toxoplasma gondii: the vaccine potential of three trivalent antigen-cocktails composed of recombinant ROP2, ROP4, GRA4 and SAG1 proteins against chronic toxoplasmosis in BALB/c mice. Experimental Parasitology, 131(1), 133-138. 
8. Echeverria PC, Matrajt M, Harb OS, Zappia MP, Costas MA, Roos DS, Dubremetz JF, Angel SO. 2005. Toxoplasma gondii Hsp90 is a potential drug target whose expression and subcellular localization are developmentally regulated. Journal of Molecular Biology, 350(4), 723-734.

9. El Hajj H, Demey E, Poncet J, Lebrun M, Wu B, Galeotti N, Fourmaux MN, Mercereau-Puijalon O, Vial H, Labesse G, Dubremetz JF. 2006. The ROP2 family of Toxoplasma gondii rhoptry proteins: proteomic and genomic characterization and molecular modeling. Proteomics, 6(21), 5773-5784.

10. Elmore SA, Jones JL, Conrad PA, Patton S, Lindsay DS, Dubey JP. 2010. Toxoplasma gondii: epidemiology, feline clinical aspects, and prevention. Trends in Parasitology, 26(4), 190-196.

11. Etheridge RD, Alaganan A, Tang K, Lou HJ, Turk BE, Sibley LD. 2014. The Toxoplasma pseudokinase ROP5 forms complexes with ROP18 and ROP17 kinases that synergize to control acute virulence in mice. Cell Host Microbe, 15(5), $537-550$.

12. Gazzinelli RT, Denkers EY, Sher A. 1993. Host resistance to Toxoplasma gondii: model for studying the selective induction of cell-mediated immunity by intracellular parasites. Infectious Agents and Disease, 2(3), 139-149.

13. Hamidinejat $\mathrm{H}$, Jalali MH, Jafari RA, Nourmohammadi K. 2014. Molecular determination and genotyping of Cryptosporidium spp. in fecal and respiratory samples of industrial poultry in Iran. Asian Pacific Journal of Tropical Medicine, 7(7), 517-520.

14. Huang B, Huang S, Chen Y, Zheng H, Shen J, Lun ZR, Wang Y, Kasper LH, Lu F. 2013. Mast cells modulate acute toxoplasmosis in murine models. PLoS One, 8(10), e77327.

15. Jensen KD, Hu K, Whitmarsh RJ, Hassan MA, Julien L, Lu D, Chen L, Hunter CA, Saeij JP. 2013. Toxoplasma gondii rhoptry 16 kinase promotes host resistance to oral infection and intestinal inflammation only in the context of the dense granule protein GRA15. Infection and Immunity, 81(6), 2156-2167.

16. Jordan KA, Hunter CA. 2010. Regulation of CD8+ T cell responses to infection with parasitic protozoa. Experimental Parasitology, 126(3), 318-325.

17. Li ZY, Chen J, Petersen E, Zhou DH, Huang SY, Song HQ, Zhu XQ. 2014. Synergy of mIL-21 and mIL-15 in enhancing DNA vaccine efficacy against acute and chronic Toxoplasma gondii infection in mice. Vaccine, 32(25), 3058-3065.

18. Liu Q, Wang F, Wang G, Zhao Q, Min J, Wang S, Cong H, Li Y, He S, Zhou H. 2014. Toxoplasma gondii: immune response and protective efficacy induced by ROP16/GRA7 multicomponent DNA vaccine with a genetic adjuvant B7-2. Human Vaccines \& Immunotherapeutics, 10(1), 184-191.

19. Luft BJ, Remington JS. 1992. Toxoplasmic encephalitis in AIDS. Clinical Infectious Diseases, 15(2), 211-222.

20. Ma GY, Zhang JZ, Yin GR, Zhang JH, Meng XL, Zhao F. 2009. Toxoplasma gondii: proteomic analysis of antigenicity of soluble tachyzoite antigen. Experimental Parasitology, 122(1), 41-46.

21. Parthasarathy S, Fong MY, Ramaswamy K, Lau YL. 2013. Protective immune response in $\mathrm{BALB} / \mathrm{c}$ mice induced by DNA vaccine of the ROP8 gene of Toxoplasma gondii. American Journal of Tropical Medicine and Hygiene, 88(5), 883-887.

22. Pulendran B. 2004. Modulating TH1/TH2 responses with microbes, dendritic cells, and pathogen recognition receptors. Immunologic Research, 29(1-3), 187-196.
23. Qiu W, Wernimont A, Tang K, Taylor S, Lunin V, Schapira M, Fentress S, Hui R, Sibley LD. 2009. Novel structural and regulatory features of rhoptry secretory kinases in Toxoplasma gondii. EMBO Journal, 28(7), 969-979.

24. Robert-Gangneux F, Dardé ML. 2012. Epidemiology of and diagnostic strategies for toxoplasmosis. Clinical Microbiology Reviews, 25(2), 264-296.

25. Rodrigues MM, Boscardin SB, Vasconcelos JR, Hiyane MI, Salay G, Soares IS. 2003. Importance of CD8 T cell-mediated immune response during intracellular parasitic infections and its implications for the development of effective vaccines. Anais da Academia Brasileira de Ciencias, 75(4), 443-468.

26. Sayles PC, Gibson GW, Johnson LL. 2000. B cells are essential for vaccination-induced resistance to virulent Toxoplasma gondii. Infection and Immunity, 68(3), 1026-1033.

27. Sharma P, Chitnis CE. 2013. Key molecular events during host cell invasion by Apicomplexan pathogens. Current Opinion in Microbiology, 16(4), 432-437.

28. Sibley LD, Adams LB, Krahenbuhl JL. 1993. Macrophage interactions in toxoplasmosis. Immunologic Research, 144(1), 38-40.

29. Solano Aguilar GI, Beshah E, Vengroski KG, Zarlenga D, Jauregui L, Cosio M, Douglass LW, Dubey JP, Lunney JK. 2001. Cytokine and lymphocyte profiles in miniature swine after oral infection with Toxoplasma gondii oocysts. International Journal for Parasitology, 31(2), 187-195.

30. Touzot M, Cacoub P, Bodaghi B, Soumelis V, Saadoun D. 2014. IFN-alpha induces IL-10 production and tilt the balance between Th1 and Th17 in Behçet disease. Autoimmunity Reviews, 14(5), 370-375.

31. Velge-Roussel F, Marcelo P, Lepage AC, Buzoni-Gatel D, Bout DT. 2000. Intranasal immunization with Toxoplasma gondii SAG1 induces protective cells into both NALT and GALT compartments. Infection and Immunity, 68(2), 969-972.

32. Villavedra M, Rampoldi C, Carol H, Baz A, Battistoni JJ, Nieto A. 2001. Identification of circulating antigens, including an immunoglobulin binding protein, from Toxoplasma gondii tissue cyst and tachyzoites in murine toxoplasmosis. International Journal for Parasitology, 31(1), 21-28.

33. Wang HL, Li YQ, Yin LT, Meng XL, Guo M, Zhang JH, Liu HL, Liu JJ, Yin GR. 2013. Toxoplasma gondii protein disulfide isomerase (TgPDI) is a novel vaccine candidate against toxoplasmosis. PLoS One, 8(8), e70884.

34. Wang HL, Yin LT, Zhang TE, Guan L, Meng XL, Liu HL, Yin GR. 2014. Construction, expression and kinase function analysis of an eukaryocyte vector of rhoptry protein 17 in Toxoplasma gondii. Zhongguo Ji Sheng Chong Xue Yu Ji Sheng Chong Bing Za Zhi, 32(1), 29-33.

35. Wang HL, Zhang TE, Yin LT, Pang M, Guan L, Liu HL, Zhang JH, Meng XL, Bai JZ, Zheng GP, Yin GR. 2014. Partial protective effect of intranasal immunization with recombinant Toxoplasma gondii rhoptry protein 17 against toxoplasmosis in mice. PLoS One, 9(9), e108377.

36. Wang PY, Yuan ZG, Petersen E, Li J, Zhang XX, Li XZ, Li HX, Lv ZC, Cheng T, Ren D, Yang GL, Lin RQ, Zhu XQ. 2012. Protective efficacy of a Toxoplasma gondii rhoptry protein 13 plasmid DNA vaccine in mice. Clinical and Vaccine Immunology, 19(12), 1916-1920.

37. Wang S, Hassan IA, Liu X, Xu L, Yan R, Song X, Li X. 2015. Immunological changes induced by Toxoplasma gondii Glutathione-S-Transferase (TgGST) delivered as a DNA vaccine. Research in Veterinary Science, 99, 157-164. 
38. Weiss LM, Dubey JP. 2009. Toxoplasmosis: a history of clinical observations. International Journal for Parasitology, 39(8), 895-901.

39. Xu Y, Zhang NZ, Tan QD, Chen J, Lu J, Xu QM, Zhu XQ. 2014. Evaluation of immuno-efficacy of a novel DNA vaccine encoding Toxoplasma gondii rhoptry protein 38 (TgROP38) against chronic toxoplasmosis in a murine model. BMC Infectious Diseases, 14, 525.

40. Yamamoto M, Takeda K. 2012. Inhibition of ATF6betadependent host adaptive immune response by a Toxoplasma virulence factor ROP18. Virulence, 3(1), 77-80.

41. Yin GR, Meng XL, Ma GY, Ma XM. 2007. Intranasal immunization with mucosal complex vaccine protects mice against Toxoplasma gondii. Zhongguo Ji Sheng Chong Xue Yu Ji Sheng Chong Bing Za Zhi, 25(4), 290-294.

42. Yuan ZG, Zhang XX, He XH, Petersen E, Zhou DH, He Y, Lin RQ, Li XZ, Chen XL, Shi XR, Zhong XL, Zhang B, Zhu XQ. 2011. Protective immunity induced by Toxoplasma gondii rhoptry protein 16 against toxoplasmosis in mice. Clinical and Vaccine Immunology, 18(1), 119-124.

43. Yuan ZG, Zhang XX, Lin RQ, Petersen E, He S, Yu M, He XH, Zhou DH, He Y, Li HX, Liao M, Zhu XQ. 2011. Protective effect against toxoplasmosis in mice induced by DNA immunization with gene encoding Toxoplasma gondii ROP18. Vaccine, 29(38), 6614-6619.

44. Zhang NZ, Chen J, Wang M, Petersen E, Zhu XQ. 2013. Vaccines against Toxoplasma gondii: new developments and perspectives. Expert Review of Vaccines, 12(11), 1287-1299.

45. Zhang NZ, Xu Y, Huang SY, Zhou DH, Wang RA, Zhu XQ. 2014. Sequence variation in Toxoplasma gondii rop17 gene among strains from different hosts and geographical locations. Scientific World Journal, 2014, 349325.

46. Zheng B, Lu S, Tong Q, Kong Q, Lou D. 2013. The virulencerelated rhoptry protein 5 (ROP5) of Toxoplasma gondii is a novel vaccine candidate against toxoplasmosis in mice. Vaccine, 31(41), 4578-4584.

Cite this article as: Wang H-L, Wang Y-J, Pei Y-J, Bai J-Z, Yin L-T, Guo R \& Yin G-R: DNA vaccination with a gene encoding Toxoplasma gondii Rhoptry Protein 17 induces partial protective immunity against lethal challenge in mice. Parasite, 2016, 23, 4.

Reviews, articles and short notes may be submitted. Fields include, but are not limited to: general, medical and veterinary parasitology; morphology, including ultrastructure; parasite systematics, including entomology, acarology, helminthology and protistology, and molecular analyses; molecular biology and biochemistry; immunology of parasitic diseases; host-parasite relationships; ecology and life history of parasites; epidemiology; therapeutics; new diagnostic tools.

All papers in Parasite are published in English. Manuscripts should have a broad interest and must not have been published or submitted elsewhere. No limit is imposed on the length of manuscripts.

Parasite (open-access) continues Parasite (print and online editions, 1994-2012) and Annales de Parasitologie Humaine et Comparée (1923-1993) and is the official journal of the Société Française de Parasitologie. 